Institute of $\mathbf{F}_{\text {ood and }} \mathbf{A g r i c u l t u r a l}_{\text {ciences }}$

\title{
Como Realizar un Plan de Gastos - Sexto Paso: Cambiar su Plan de Gastos ${ }^{1}$
}

Nayda I Torres ${ }^{2}$

Usted puede cambiar su plan de gastos. Repase sus ingresos, deudas, y gastos. Eche una mirada a sus gastos flexibles. Estos gastos se pueden controlar reduciendo las necesidades o ajustando cuanto se gasta en ellos. Recuerde una simple regla: Si le ayuda a alcanzar sus metas, hágalo. ¡Si no, no lo haga!

\section{Aproveche al máximo sus posesiones}

\section{Casa}

- Mantenga la casa limpia.

- Repare las averías tan pronto como ocurran.

\section{Ropas}

- Mantenga la ropa limpia y destine un lugar para su almacenamiento.

- Limpie las manchas lo antes posible.

\section{Automóviles y electrodomésticos}

- Siga las pautas de mantenimiento del fabricante.
- Vigile y mantenga los niveles de fluido adecuados y la presión de los neumáticos aconsejada por el fabricante.

\section{Alimentos}

- Almacene la comida apropiadamente.

- Use los alimentos antes de que caduquen.

\section{Gastos Personales}

- Coma alimentos que sean nutritivos.

- Haga ejercicio regularmente.

- Elimine gastos poco saludables y demasiado costosos.

\section{Comprar Productos y Servicios}

- Compartir. Comparta ideas, artículos y habilidades con otros. Compre en volumen y comparta los artículos y gastos con un amigo.

- Tomar Prestado. ¿Por qué comprar algo que puede tomar prestado de su vecino?

1. Este documento es la Hojuela FCS7172-Span, una serie del Departamento de Ciencias de la Familia, Juventud y Comunidad, Servicio de Extensión Cooperativa de Florida, Instituto de Alimentos y Ciencias Agrícolas, Universidad de Florida. Fecha de publicación: Octubre 2002. Por favor visite el web de EDIS http://edis.ifas.ufl.edu

2. Escrito por Nayda I. Torres, Profesora, Familia y Economía del Consumidor y la versión en Inglés ha sido revisada por Josephine Turner, CFP, Profesora, Familia y Economía del Consumidor, Servicio de Extensión Cooperativa, Departamento de Ciencias de la Familia, Juventud y Comunidad, Instituto de Alimentos y Ciencias Agrícolas, University of Florida, Gainesville, 32611. Traducido por: Sergio Romero.

El Instituto de Alimentos y Ciencias Agrícolas es un patrono que ofrece igualdad de oportunidad de empleo, autorizado a proveer investigación, información educativa y otros servicios a individuos y a instituciones que ejerzan sus funciones sin tomar en consideración raza, color, sexo, edad, incapacidad o nacionalidad. Para información sobre como obtener otras publicaciones del Servicio de Extensión, comuníquese con la Oficina del Servicio de Extensión Cooperativa de su Condado. Servicio de Extensión Cooperativa de Florida / Instituto de Alimentos y Ciencias Agrícolas / Universidad de Florida, Christine Taylor Waddill, Decano 
- Intercambiar. Se pueden intercambiar productos o habilidades. Intercambie o venda las cosas que usted no necesite.

- Reparar o Construir. Puede ser más barato construir o reparar si usted puede hacerlo, tiene el tiempo y las herramientas necesarias.

- Investigar antes de Comprar. Compre productos en rebajas. Utilice tiendas de descuentos o de productos usados.
- Negociar. Negocie para conseguir mejores precios.

- Pagar las facturas a tiempo. Es más barato pagar las facturas a tiempo ya que algunos negocios cobran cuotas especiales o intereses por pagar tarde. 